\title{
Chronic Recurrent Multifocal Osteomyelitis
}

\section{Kronik Rekürren Multifokal Osteomiyelit}

\author{
Şule ArıCI ${ }^{1}$, Eren Çağan², Havva Hasret Çağan ${ }^{3}$ \\ ${ }^{1}$ Clinic of Pediatrics, Istanbul Pasabahce State Hospital, Istanbul, Turkey \\ ${ }^{2}$ Clinic of Pediatric Infectious Diseases, Bursa Sevket Yilmaz State Hospital, Bursa, Turkey \\ ${ }^{3}$ Clinic of Pediatric Allergy and Immunology Diseases, Bursa Sevket Yilmaz State Hospital, Bursa, Turkey
}

Cite this article as: Arıcı Ş, Çağan E, Çağan HH. Chronic recurrent multifocal osteomyelitis. J Pediatr Inf 2019;13(1):e35-e38

\section{Abstract}

Chronic recurrent multifocal osteomyelitis (CRMO) is a rare non-infectious inflammatory bone disease of unknown etiology. It presents with recurrent episodes of bone pain and fever, resembling bacterial osteomyelitis, but cultures of lesions are sterile and it is unresponsive to antibiotic therapy. We report a case of 11-year-old girl diagnosed with CRMO, who presented with chronic pain and swelling of bilateral legs. We want to emphasize that CRMO should be kept in mind in the differential diagnosis of recurrent, multifocal bone pain and clinical osteomyelitis.

Keywords: Chronic recurrent multifocal osteomyelitis, chronic non-infectious osteomyelitis

\section{Introduction}

Chronic recurrent multifocal osteomyelitis (CRMO) is a self-limiting, non-infectious, auto-inflammatory disease that is often seen in children and adolescents. It is characterized by recurrent painful and symmetrically involved bone lesions. The etiology of this rare disease has not been fully elucidated (1). Female/male ratio is 5/1 in this disease from which adolescent girls are more affected. It is most common between the ages of 4 and 14 years (2). CRMO is a condition where signs

\begin{abstract}
Öz
Kronik rekürren multifokal osteomiyelit (KRMO) etyolojisi tam aydınlatılamamış, nadir görülen enfeksiyöz olmayan enflamatuvar kemik hastalığıdır. Hastalık tekrarlayan kemik ağrısı ve ateş atakları ile seyreder. Klinik olarak bakteriyel osteomiyeliti taklit etse de kültürlerde üreme olmaz ve antibiyotik tedavisine yanıt vermez. Bu yazıda bilateral kronik bacak ağrısı ve şişlik şikayeti ile başvuran ve KRMO tanısı alan 11 yaşında bir kız olguyu sunduk. Bu olgu sebebi ile tekrarlayan, multifokal kemik ağrısı olup osteomiyelit kliniği olan hastalarda KRMO'nun ayrıcı tanıda düşünülmesi gerektiğini vurgulamak istedik.
\end{abstract}

Anahtar Kelimeler: Kronik rekürren multifokal osteomiyelit, kronik enfeksiyöz olmayan osteomiyelit

of inflammation are observed on the bone that is involved with insidious mild or moderate pain. It usually involves the metaphysis of long bones; it is often symmetrical and bilateral. It may present with lytic lesions or sclerosis with varying degrees in radiology. It is followed by exacerbation and recovery attacks $(3,4)$.

In this report, we present an 11-year-old girl who consulted to us due to chronic recurrent pain and swelling in both legs and was diagnosed with CRMO after the clinical and laboratorial differential diagnosis.

Correspondence Address / Yazışma Adresi

Şule Arıcı

İstanbul Paşabahçe Devlet Hastanesi,

Çocuk Sağlığı ve Hastalıkları Kliniği,

İstanbul-Türkiye

E-mail: dr.suledarende@gmail.com 


\section{Case Report}

An eleven - year - old female patient consulted to us due to pain and swelling in both legs. It was learned that the patient had complaints for 15 days and had a partial response to the painkillers, it repeated 4-5 times in the last five years, and she had received inpatient anti-biotherapy for 3 times due to infectious osteomyelitis, the period of attack changed between 15 days and two months and she had poor appetite during the attack period. The patient did not have any additional complaints. Her family did not include someone with similar complaints. However, it was learned that her mother had been diagnosed with joint rheumatism. Body temperature was $36.7^{\circ} \mathrm{C}$, pulse was $90 / \mathrm{min}$, arterial blood pressure was $105 / 60 \mathrm{mmHg}$, respiratory rate was $18 / \mathrm{min}$, and oxygen saturation was $98 \%$. Her length was $148 \mathrm{~cm}$ (40\% percentile), and weight was $29 \mathrm{~kg}$ (3\% percentile). On physical examination, the anterior part of both legs had bright appearance, and partial swelling and temperature increase were observed. There was also an excessive tenderness with palpation on the anterior aspect of both legs. The patient could hardly walk due to pain. There were no pathological findings in other system examinations. White blood cell count was 13.320/uL (polymorphonuclear neutrophils $65-70 \%$, lymphocytes $25-30 \%$, monocytes $2-3 \%$, eosinophils 2-3\%, no atypical cells), hemoglobine was $13 \mathrm{~g} / \mathrm{dL}$, platelet was 486.000/uL, C-reactive protein (CRP) was $19.10 \mathrm{mg} / \mathrm{L}$ (0-5), and erythrocyte sedimentation rate was $49 \mathrm{~mm} / \mathrm{h}$. Vitamin D was $11.2(25-80) \mathrm{ng} / \mathrm{mL}$, parathormone was $61.6 \mathrm{pg} / \mathrm{mL}$, calcium was $10 \mathrm{mg} / \mathrm{dL}$, alkaline phosphatase was $350 \mathrm{U} / \mathrm{L}$, TSH was $2.24 \mathrm{MIU} / \mathrm{L}$, free T4 was $1.51 \mathrm{ng} / \mathrm{dL}$, ANA was negative, anti-ds DNA was $9.8 \mathrm{IU} / \mathrm{mL}$ (negative), rheumatoid factor was $9.75 \mathrm{IU} / \mathrm{mL}$ (negative) and PPD was $8 \mathrm{~mm}$, and Quantiferon was negative. Other laboratory tests were unremarkable. Direct radiographs of the patient revealed several lesions causing medullar heterogeneous density increase and lamellar periost reaction in the right tibia medial-distal, left tibia 1/3 distal and distal portion of the left femur. (Picture 1,2). Magnetic resonance imaging (MRG) of both legs showed reactive thickening of the periosteum and contrast uptake of the intramedullary component. (Picture 3,4). Bone scintigraphy revealed an increase in osteoblastic activity accompanied by hyper-perfusion in bilateral tibia and left femur. Samples were taken from the distal $1 / 3$ of the right tibia where lesions were more for both culture and histopathology. No reproduction was observed in the cultivation of aerop, anaerobic microorganisms and tuberculosis. Histopathological examination of the biopsy revealed fibro-angiomatous hyperplasia in the bone. Clinical and laboratory malignancy and endocrinological pathology were not considered. Due to the absence of skin involvement, auto-inflammatory recurrent osteomyelitis syndromes with skin involvement such as Majeed, SAPHO

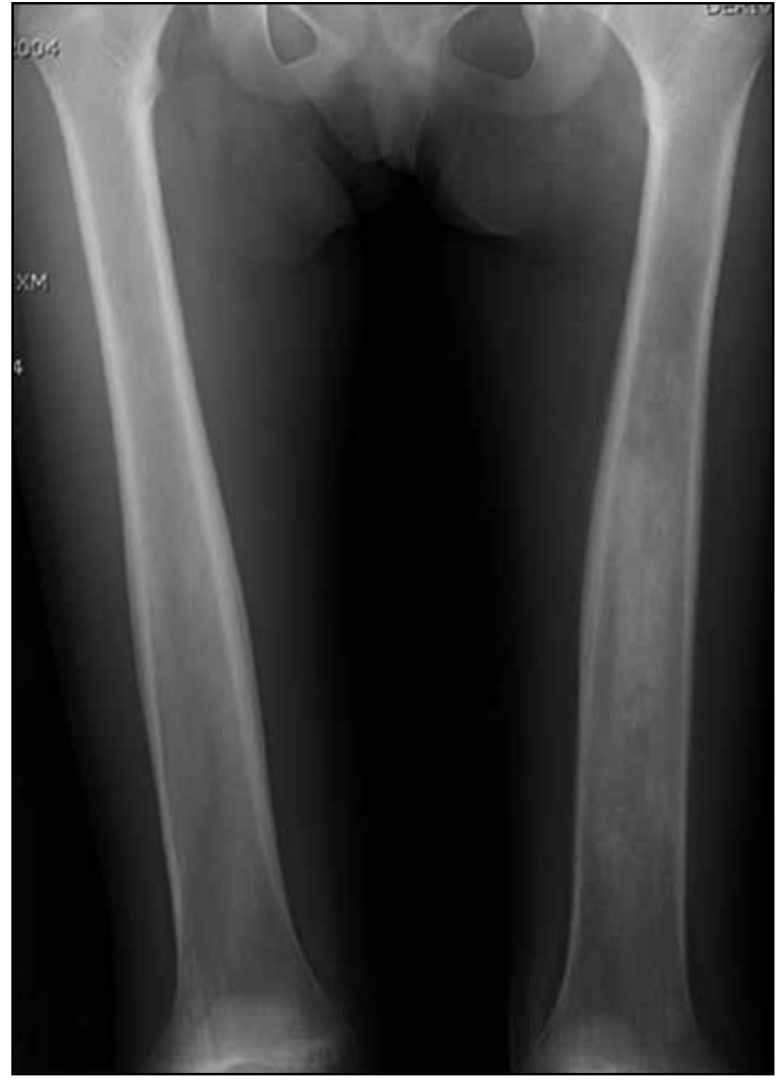

Figure 1. Medullary heterogeneity and lamellar periosteal reaction at distal part of left femur, in direct radiography.

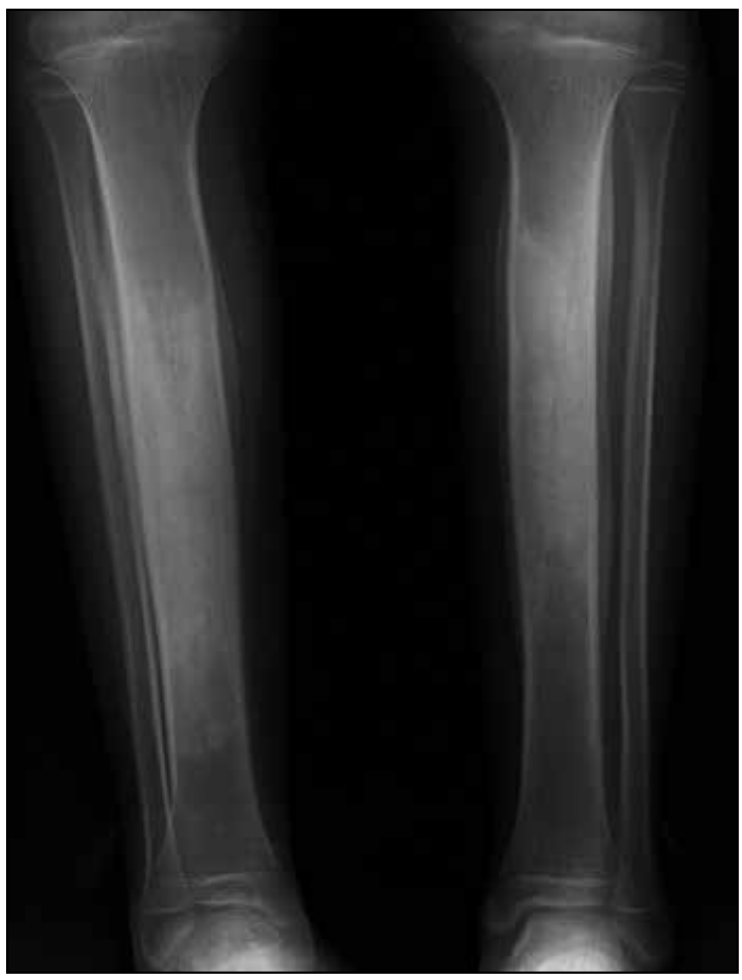

Figure 2. Medullary heterogeneity and lamellar periosteal reaction at distal part of right and left tibia, in direct radiography. 


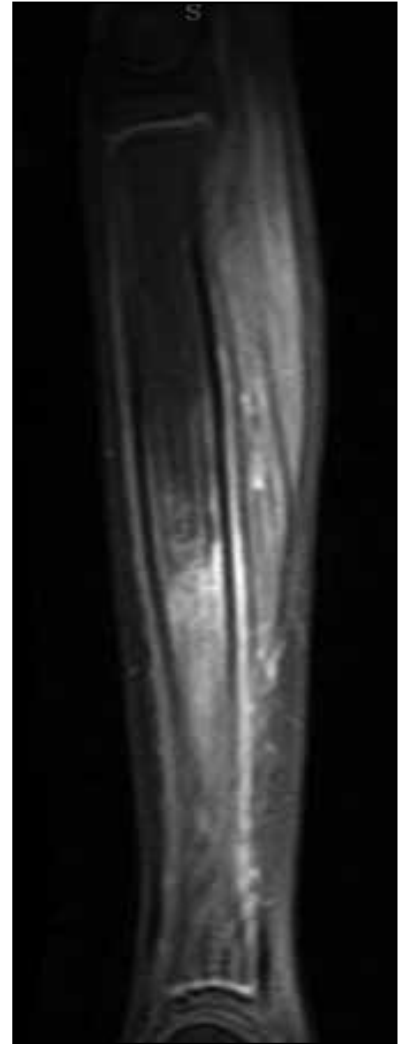

Figure 3. Periosteal thickening and intramedullary contrast enhancment at left cruris in magnetic resonance imaging.

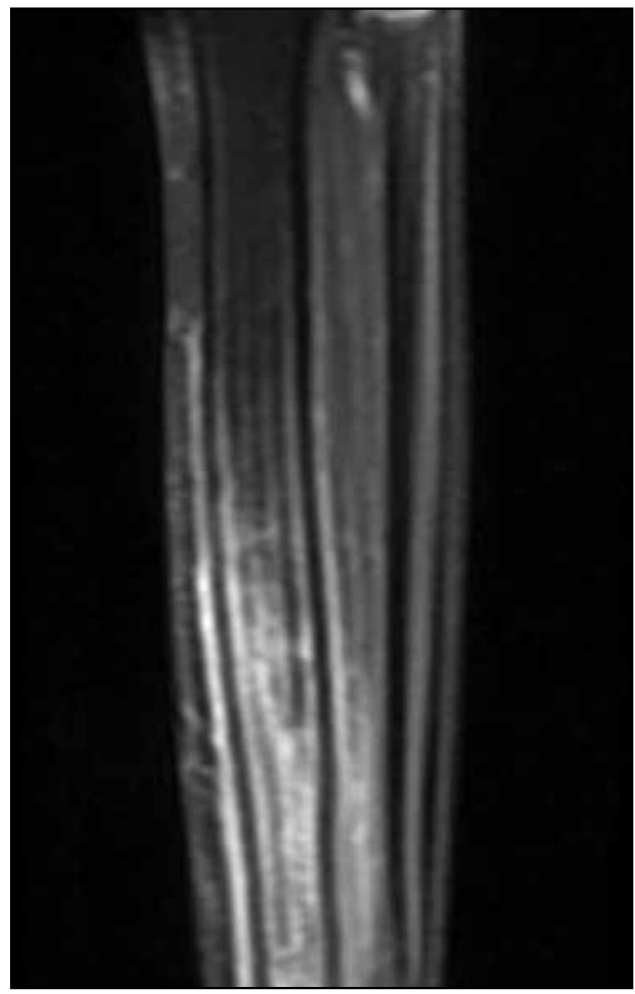

Figure 4. Periosteal thickening and intramedullary contrast enhancment at right cruris in magnetic resonance imaging. and DIRA syndrome were excluded. With the current clinical and laboratory findings, she was diagnosed with CRMO. The patient was started to NSAID to relieve acute symptoms and was discharged after all her complaints had improved. In the follow-up, methotrexate was planned, if the attack frequency did not decrease and outpatient follow-up was initiated.

\section{Discussion}

CRMO is a kind of non-infective inflammatory osteomyelitis seen in children. Although there is no a large epidemiological study on its incidence and prevalence, its incidence is considered to be 1: 1000000 (5).

Although the metaphyses of the long bones are usually involved, the spine, pelvis and shoulder are also involved. It starts with local pain and swelling in the affected bone. Fever and loss of appetite are possible systemic signs. Moderate increases in acute phase reactants may occur. Multifocal involvement is seen. The clinical course consists of exacerbation and healing processes $(2,4)$.

The etiology of CRMO has not been fully elucidated. Some of the patients with CRMO may have involvement of the eyes, skin and gastrointestinal tract. This suggests that it may be associated with inflammatory diseases. Another opinion is that it may be an auto-inflammatory disease (1). The CRMO is a diagnosis of retraction and the differential diagnosis should be made carefully. Besides the clinical features, microbiological, histopathological and imaging methods are used for diagnosis. Reproduction is not observed in blood cultures and bone cultures taken from the lesion. Histopathological examination reveals polymorphonuclear cell dominance of the disease in the early period and lymphocyte dominance in the late period. Also necrosis, fibrosis and new bone formations can be seen. Histopathological examination is important for the exclusion of neoplasia. Osteomyelitis findings are observed on bone scintigraphy and radiography. In addition, magnetic resonance imaging, which is a very sensitive method in the evaluation of joints and soft tissues, is very useful in demonstrating both osteomyelitis and differential diagnosis of the disease. It should be noted that osteosarcoma and malignancy such as Ewing's sarcoma and bacterial sub-acute osteomyelitis should be considered in the differential diagnosis of the disease (1,35). In our case, no microorganism could be isolated. The fact that our patient had complaints for 5 years and that the attacks were repeated 4-5 times a year, and the findings supporting osteomyelitis, which had more than one involvement in the radiological setting, have supported the diagnosis of CRMO. Physical examination and radiological examination of the patient revealed no significant findings such as deformity and ankylosis. The clinical features, physical examination, 
laboratory evaluation, microbiological and histopathological examination of the patient and other possible diagnoses were excluded and our diagnosis of CRMO was supported.

There are different practices in the treatment of CRMO. Most cases benefit from non-steroidal anti-inflammatory medicines. In addition; patients for whom remission was achieved with steroid therapy, bisphosphonates, sulfasalazine, interferon and anti-TNF-alpha have been reported $(1,3,6)$. In our case, the symptoms were controlled with non-steroidal anti-inflammatory treatment. The patient was discharged after all her complaints had improved.

As a result; in patients with possible osteomyelitis in clinical and radiological way, chronic recurrent osteomyelitis should be considered in the differential diagnosis if there are multifocal involvement, and especially, recurrent attacks. Early diagnosis is important in terms of prevention of unnecessary investigations and treatment and prevention of complications in upcoming periods.

Informed Consent: Patient consent was obtained.

Peer-review: Externally peer-reviewed.

Author Contributions: Concept - ŞA; Design - ŞA, EÇ; Supervision - ŞA, HHÇ; Data Collection and/or Processing - ŞA; Literature Review ŞA, EÇ, HHÇ; Writing - ŞA; Critical Review - EÇ, HHÇ.

Conflict of Interest: The authors have not reported a conflict of interest.

Financial Disclosure: There is no financial support in this study.

\section{References}

1. Girschick HJ, Zimmer C, Klaus G, Darge K, Dick A, Morbach H. Chronic recurrent multifocal osteomyelitis: what is it and how should it be treated? Nat Clin Pract Rheumatol 2007;3:733-8.

2. Ertürk C, Altay MA, Aşkar H. Osteomiyelitin farklı klinik şekilleri. The different forms of osteomyelitis. TOTBID Dergisi 2011;10:225-32.

3. Girschick HJ, Raab P, Surbaum S, Trusen A, Kirschner S, Schneider $P_{1}$ et al. Chronic non-bacterial osteomyelitis in children. Ann Rheum Dis 2005;64:279-85.

4. Kıter E, Havıtçıoğlu H. Kronik rekürrent multifokal osteomiyelit. Acta Orthop Traumatol Turc 1998;32:248-52.

5. Alshammari A, Usmani S, Elgazzar AH, Ashkanani RA. Chronic recurrent multifocal osteomyelitis in children: a multidisciplinary approach is needed to establish a diagnosis. World J Nucl Med 2013;12:120-3.

6. Cavalcanti AS, Sena EG, Cavalcanti SV, Cavalcanti FS, Duarte ALBP. Chronic Recurrent Multifocal Osteomyelitis: Treatment with a Tumor Necrosis Factor-Alpha Inhibitor. Turk J Rheumatol 2012;27:262-6. 